\title{
Synthesis and Spectroscopic Characterization of Tin(II) and Tin(IV) Complexes Containing 2,3,5,6-Tetrakis $\left(\alpha\right.$-pyridyl)pyrazine as a Bridging Ligand ${ }^{\#}$
}

\author{
Rodrigo S. Bitzer ${ }^{a}$, Wagner M. Teles ${ }^{b}$, Anuar Abras $^{c}$, José Domingos Ardisson $^{d}$ \\ and Carlos A. L. Filgueiras *,a \\ ${ }^{a}$ Instituto de Química, Universidade Federal do Rio de Janeiro, CP 68563, 21945-970 Rio de Janeiro - RJ, Brazil \\ ${ }^{b}$ Departamento de Química-ICE, Universidade Federal de Juiz de Fora, 36036-330 Juiz de Fora - MG, Brazil \\ ${ }^{c}$ Departamento de Física-ICEx, Universidade Federal de Minas Gerais, 30161-970 Belo Horizonte - MG, Brazil \\ ${ }^{d}$ Centro de Desenvolvimento da Tecnologia Nuclear-CNEN, 31270-910 Belo Horizonte - MG, Brazil
}

\begin{abstract}
Neste trabalho foram investigadas as reações entre o ligante heterocíclico nitrogenado 2,3,5,6tetraquis ( $\alpha$-piridil)pirazina, TPP, e seis precursores de estanho, a saber: $\mathrm{SnCl}_{2}, \mathrm{SnX}_{4}(\mathrm{X}=\mathrm{Cl}$ ou $\mathrm{Br})$, $\mathrm{SnRCl}_{3}(\mathrm{R}=\mathrm{Ph}$ ou $\mathrm{Me})$ e $\mathrm{SnPh}_{2} \mathrm{Cl}_{2}$. Os produtos foram caracterizados por microanálise $(\mathrm{C}, \mathrm{H}, \mathrm{N}$ e Sn), espectroscopia no infravermelho $\left(4000-200 \mathrm{~cm}^{-1}\right)$, RMN de ${ }^{1} \mathrm{H},{ }^{13} \mathrm{C}\left\{{ }^{1} \mathrm{H}\right\},{ }^{13} \mathrm{C}-\mathrm{CP} / \mathrm{MAS}$, ${ }^{119} \mathrm{Sn}$ e ${ }^{119} \mathrm{Sn}$-MAS, bem como por espectroscopia Mössbauer de ${ }^{119} \mathrm{Sn}$. Todas as reações levaram ao isolamento de complexos bimetálicos, nos quais o TPP se comportou como um ligante bis-bidentado em ponte, ligando-se a cada centro metálico através de dois átomos de nitrogênio piridínicos. Este modo de coordenação é ainda raro na literatura e, pela primeira vez, é observado em complexos de TPP com um metal representativo.
\end{abstract}

In this work we investigated the reactivity of the nitrogen heterocyclic ligand 2,3,5,6-tetrakis $(\alpha$ pyridyl)pyrazine, TPP, towards six tin-containing reagents, namely $\mathrm{SnCl}_{2}, \mathrm{SnX}_{4}(\mathrm{X}=\mathrm{Cl}$ or $\mathrm{Br})$, $\mathrm{SnRCl}_{3}(\mathrm{R}=\mathrm{Ph}$ or $\mathrm{Me})$, and $\mathrm{SnPh}_{2} \mathrm{Cl}_{2}$. The products were characterized by microanalysis $(\mathrm{C}, \mathrm{H}, \mathrm{N}$, and Sn), IR spectroscopy $\left(4000-200 \mathrm{~cm}^{-1}\right),{ }^{1} \mathrm{H},{ }^{13} \mathrm{C}\left\{{ }^{1} \mathrm{H}\right\},{ }^{13} \mathrm{C}-\mathrm{CP} / \mathrm{MAS},{ }^{119} \mathrm{Sn}$, and ${ }^{119} \mathrm{Sn}-\mathrm{MAS}$ NMR spectroscopy, as well as by ${ }^{119} \mathrm{Sn}$ Mössbauer spectroscopy. All reactions yielded bimetallic adducts, in which TPP behaved as a bis-bidentate bridging ligand, binding to each metallic center through two pyridine nitrogen atoms. This coordination mode is so far quite rare and, for the first time, is reported for main group metal-TPP complexes.

Keywords: $\mathrm{Sn}(\mathrm{II}), \mathrm{Sn}(\mathrm{IV})$, bimetallic complexes, 2,3,5,6-tetrakis( $\alpha$-pyridyl)pyrazine

\section{Introduction}

2,3,5,6-tetrakis $(\alpha$-pyridyl)pyrazine, TPP, is a versatile ambidentate ligand containing six Lewis-basic nitrogen sites and at least seven different coordination modes with transition metals. ${ }^{1-16}$ The seven chelating modes hitherto encountered for TPP are illustrated in Figure 1. The reactivity of this ligand towards transition metal species has attracted considerable attention over the past twenty years. ${ }^{1-16}$ However, studies of reactions between TPP and main group metal compounds are absent in the literature. Owing to this paucity of information, we decided to investigate the reactivity and coordinating behavior of

*e-mail: calf@iq.ufrj.br

\# To the memory of Dr. Wagner Magno Teles (1971-2004)
TPP towards $\mathrm{Sn}(\mathrm{II})$ and $\mathrm{Sn}(\mathrm{IV})$ compounds, namely $\mathrm{SnCl}_{2}$, $\mathrm{SnX}_{4}(\mathrm{X}=\mathrm{Cl}$ or Br$), \mathrm{SnRCl}_{3}(\mathrm{R}=\mathrm{Ph}$ or $\mathrm{Me})$, and $\mathrm{SnPh}_{2} \mathrm{Cl}_{2}$. The various complexes thus produced were characterized by a number of different spectroscopic methods.

The coordination chemistry of tin, particularly that of organotin compounds, is quite rich. ${ }^{17-19}$ However, this work shows that the stannylated products described herein are all bimetallic adducts and exhibit a similarity of structural behavior. Regardless of the stannylated reagent, TPP coordinates each tin atom through two pyridine nitrogen atoms, in the bis-bidentate 1 chelating mode (Figure 1). This sort of TPP coordination mode was first reported for the cationic part of the salt $\left\{\left[\mathrm{Pt}\left(\mathrm{PEt}_{3}\right) \mathrm{Cl}\right]_{2}-\mu\right.$ $\mathrm{TPP}\}\left[\mathrm{Pt}\left(\mathrm{PEt}_{3}\right)\left(\mathrm{SnCl}_{3}\right)_{4}\right]^{12}$ and is reproduced in the present study. 


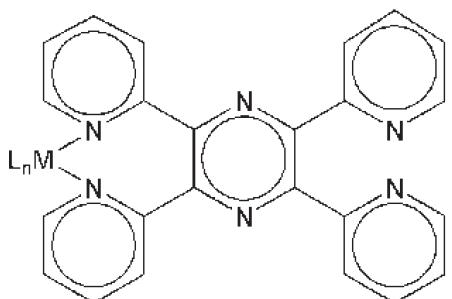

mono-bidentate 1

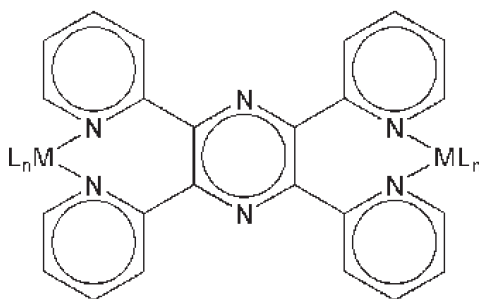

bis-bidentate 1<smiles>[Y19]c1c(-c2ccccn2)c(-c2ccccn2)nc(-c2ccccn2)c1-c1ccccn1</smiles>

mono-bidentate 2<smiles>[Y19]C1=C(c2ccccn2)C(c2ccccn2)=C(c2ccccn2)N([Y19])C1=C</smiles>

bis-bidentate 2

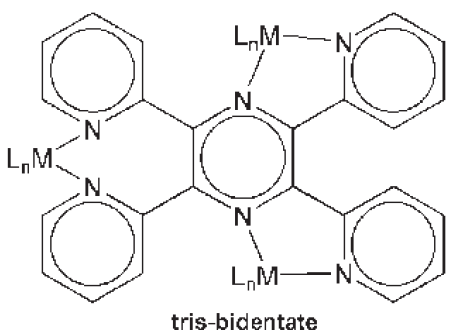<smiles></smiles>

mono-tridentate

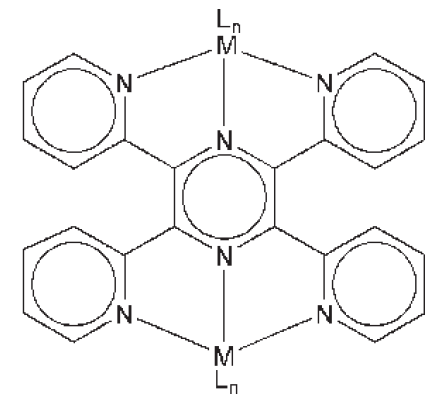

bis-tridentate

Figure 1. The seven coordination modes reported for 2,3,5,6-tetrakis( $\alpha$-pyridyl)pyrazine.

\section{Experimental}

\section{General procedures}

All reactions were carried out under an Ar or $\mathrm{N}_{2}$ atmosphere using Schlenk glassware and vacuum/inertgas line manipulation techniques. Solvents were dried by standard procedures and distilled immediately prior to use. 2,3,5,6-tetrakis $(\alpha$-pyridyl)pyrazine (TPP) was synthesized according to Goodwin \& Lions's method. ${ }^{20}$ All other chemicals were obtained from commercial sources (Strem or Aldrich) and used as received.

\section{Physical measurements}

Decomposition points were determined on a Mel-Temp II (Lab. Devices, Inc.) apparatus. Elemental analyses (C, H, and N) were conducted on a Perkin-Elmer $2400 \mathrm{CHN}$ Elemental Analyzer. Tin was analyzed on a Hitachi Z-8200 atomic absorption spectrophotometer. IR spectra were recorded either on a 283B Perkin-Elmer or on a MagnaIR760 FTIR Nicolet spectrometer. The IR spectra were obtained in the $4000-200 \mathrm{~cm}^{-1}$ range using CsI pellets. ${ }^{1} \mathrm{H}$ and ${ }^{13} \mathrm{C}\left\{{ }^{1} \mathrm{H}\right\}$ NMR spectra in solution were acquired from a Bruker DRX200 instrument operating at 200.00 and $50.30 \mathrm{MHz}$, respectively. The solution ${ }^{119} \mathrm{Sn}$ NMR spectra were obtained from a Bruker DRX400 spectrometer operating at $149.17 \mathrm{MHz}$. Both ${ }^{13} \mathrm{C}-\mathrm{CP} / \mathrm{MAS}$ and ${ }^{119} \mathrm{Sn}-$ MAS spectra were recorded on a Bruker DRX300 spectrometer operating at 75.47 and $111.92 \mathrm{MHz}$, respectively. In order to obtain the isotropic chemical shift values, the sample was spun at 6 and $7.5 \mathrm{kHz}$ in the ${ }^{13} \mathrm{C}-\mathrm{CP} / \mathrm{MAS}$ spectra and also at $8 \mathrm{kHz}$ in the ${ }^{119} \mathrm{Sn}-\mathrm{MAS}$ spectra. All NMR studies were performed at room temperature, and the chemical shift values were determined in relation to $\mathrm{SiMe}_{4}$ for the ${ }^{1} \mathrm{H}$ and ${ }^{13} \mathrm{C}$ nuclei and to an external reference of $\mathrm{SnMe}_{4}$ for the ${ }^{119} \mathrm{Sn}$ nucleus. ${ }^{119} \mathrm{Sn}$ Mössbauer spectra were obtained from a constant acceleration spectrometer moving a $\mathrm{CaSnO}_{3}$ source at room temperature. The samples were analyzed at liquid $\mathrm{N}_{2}$ temperature, and the isomer shift values are given with respect to that source. All Mössbauer spectra were computerfitted assuming Lorentzian lineshapes.

Synthesis of $\left[\left(\mathrm{SnCl}_{4}\right)_{2}-\mu-\mathrm{TPP}\right](\mathbf{1})$ and $\left[\left(\mathrm{SnBr}_{4}\right)_{2}-\mu-\mathrm{TPP}\right](2)$

A solution of $\mathrm{SnX}_{4}(\mathrm{X}=\mathrm{Cl}: 0.20 \mathrm{~mL}, 0.46 \mathrm{~g}, 1.76 \mathrm{mmol}$; $\mathrm{X}=\mathrm{Br}: 0.23 \mathrm{~mL}, 0.77 \mathrm{~g}, 1.76 \mathrm{mmol}$ ) was added under constant magnetic stirring to a suspension of TPP $(0.34 \mathrm{~g}$, $0.88 \mathrm{mmol})$ in $\mathrm{EtOH}(35 \mathrm{~mL})$. When $\mathrm{X}=\mathrm{Cl}, 1$ immediately precipitated as a white solid. When $\mathrm{X}=\mathrm{Br}$, the resulting solution was refluxed for $2 \mathrm{~h}$ and cooled to room 
temperature, leading to the formation of $\mathbf{2}$ as a yellow powder. Both $\mathbf{1}$ and $\mathbf{2}$ were filtered off, washed with EtOH and $\mathrm{Et}_{2} \mathrm{O}$, and dried under vacuum. The products were recrystallized from a 1:1 mixture of $\mathrm{EtOH}$ and $\mathrm{MeCN}$, yielding $0.60 \mathrm{~g}$ of $\mathbf{1}(75 \%)$ and $0.69 \mathrm{~g}$ of $2(63 \%)$.

Data for 1. mp: $283{ }^{\circ} \mathrm{C}$ (dec.). Anal. Calc. for $\mathrm{C}_{24} \mathrm{H}_{16} \mathrm{~N}_{6} \mathrm{Cl}_{8} \mathrm{Sn}_{2}: \mathrm{C}, 31.7 ; \mathrm{H}, 1.8 ; \mathrm{N}, 9.2 ; \mathrm{Sn}, 26.1 \%$. Found: $\mathrm{C}, 32.4 ; \mathrm{H}, 1.7 ; \mathrm{N}, 9.1 ; \mathrm{Sn}, 26.2 \%$. IR $v_{\max } / \mathrm{cm}^{-1}: v(\mathrm{CH})$, $3060(\mathrm{~m}) ; v(\mathrm{CC} / \mathrm{CN}), 1594(\mathrm{~s}), 1570(\mathrm{~s}), 1485(\mathrm{~s}), 1390(\mathrm{~s}) ;$ $\delta(\mathrm{CH}), 771(\mathrm{~s}), 740(\mathrm{~s}) ; v(\mathrm{Sn}-\mathrm{N}), 409(\mathrm{w}) ; v(\mathrm{Sn}-\mathrm{Cl}), 279(\mathrm{~s})$. ${ }^{1} \mathrm{H} \mathrm{NMR}\left(\mathrm{DMF}_{-}{ }_{7}\right), \delta$ (ppm): 8.57 (4H, m, H6); 8.36-8.24 (8H, m, H3, H4); 7.96 (4H, m, H5). ${ }^{13} \mathrm{C}\left\{{ }^{1} \mathrm{H}\right\}$ NMR (DMF$\left.d_{7}\right), \delta(\mathrm{ppm}): 157.3$ (C2, pyrazine ring); $154.2(\mathrm{C} 2) ; 151.8$ (C6); 143.5 (C3); 139.2 (C4); 130.3 (C5).

Data for 2. mp: $257{ }^{\circ} \mathrm{C}(\mathrm{dec})$. Anal. Calc. for $\mathrm{C}_{24} \mathrm{H}_{16} \mathrm{~N}_{6} \mathrm{Br}_{8} \mathrm{Sn}_{2}: \mathrm{C}, 22.8 ; \mathrm{H}, 1.3 ; \mathrm{N}, 6.6 ; \mathrm{Sn}, 18.8 \%$. Found: C, 23.4; H, 1.4; N, 6.8; Sn, 19.5\%. IR $v_{\max } / \mathrm{cm}^{-1}: v(\mathrm{CH})$, 3064 (m); $v(\mathrm{CC} / \mathrm{CN}), 1590$ (s), 1573 (s), 1489 (s), 1393 (s); $\delta(\mathrm{CH}), 778(\mathrm{~s}), 745(\mathrm{~s}) ; \boldsymbol{v}(\mathrm{Sn}-\mathrm{N}), 394(\mathrm{w}) .{ }^{1} \mathrm{H} \mathrm{NMR}\left(\mathrm{CD}_{3} \mathrm{CN}\right)$, $\delta$ (ppm): 8.54 (4H, m, H6); 8.38-8.27 (8H, m, H3, H4); 7.91 $(4 \mathrm{H}, \mathrm{m}, \mathrm{H} 5) .{ }^{13} \mathrm{C}\left\{{ }^{1} \mathrm{H}\right\}$ NMR $\left(\mathrm{CD}_{3} \mathrm{CN}\right), \delta$ (ppm): $156.2(\mathrm{C} 2$, pyrazine ring); 152.7 (C2); 151.4 (C6); 142.3 (C3); 140.8 (C4); 131.6 (C5).

Synthesis of [( $\left.\left.\mathrm{SnPhCl}_{3}\right)_{2}-\mu-\mathrm{TPP}\right](3),\left[\left(\mathrm{SnMeCl}_{3}\right)_{2}-\mu-\mathrm{TPP}\right]$ (4), and $\left[\left(\mathrm{SnPh}_{2} \mathrm{Cl}_{2}\right)_{2}-\mu-\mathrm{TPP}\right](5)$

To a suspension of TPP $(0.15 \mathrm{~g}, 0.39 \mathrm{mmol})$ in $\mathrm{EtOH}$ $(30 \mathrm{~mL})$, the appropriate organotin chloride, $\mathrm{SnR}_{4-\mathrm{n}} \mathrm{Cl}_{\mathrm{n}}(\mathrm{n}$ $=3, \mathrm{R}=\mathrm{Ph}: 0.13 \mathrm{~mL}, 0.24 \mathrm{~g}, 0.78 \mathrm{mmol} ; \mathrm{n}=3, \mathrm{R}=\mathrm{Me}$ : $0.19 \mathrm{~g}, 0.78 \mathrm{mmol} ; \mathrm{n}=2, \mathrm{R}=\mathrm{Ph}: 0.27 \mathrm{~g}, 0.78 \mathrm{mmol}$ ), was added under vigorous magnetic stirring. Each reaction mixture was kept under reflux for $6 \mathrm{~h}$, and then, reduction of the volume to $2 \mathrm{~mL}$ was performed. The precipitation of the products was induced by addition of a 2:1 mixture of THF:hexane. The products were separated by filtration, washed with $\mathrm{EtOH}$ and $\mathrm{Et}_{2} \mathrm{O}$, and dried under vacuum. The isolated complexes were recrystallized from a 1:1:2 mixture of DMF:hexane:EtOH, yielding $0.23 \mathrm{~g}$ of $\mathbf{3}(60 \%)$, $0.21 \mathrm{~g}$ of $\mathbf{4}(61 \%)$, and $0.24 \mathrm{~g}$ of $\mathbf{5}(58 \%)$.

Data for 3. mp: $270{ }^{\circ} \mathrm{C}(\mathrm{dec})$. Anal. Calc. for $\mathrm{C}_{36} \mathrm{H}_{26} \mathrm{~N}_{6} \mathrm{Cl}_{6} \mathrm{Sn}_{2}: \mathrm{C}, 43.6 ; \mathrm{H}, 2.6 ; \mathrm{N}, 8.5 ; \mathrm{Sn}, 23.9 \%$. Found: $\mathrm{C}, 44.3 ; \mathrm{H}, 2.7$; N, 8.9; Sn, 24.3\%. IR $v_{\max } / \mathrm{cm}^{-1}: v(\mathrm{CH})$, $3085(\mathrm{~m}), 3068(\mathrm{~m}) ; v(\mathrm{CC} / \mathrm{CN}), 1610(\mathrm{~s}), 1576(\mathrm{~s}), 1490$ (s), $1450(\mathrm{~s}) ; \delta(\mathrm{CH}), 772(\mathrm{~s}), 730(\mathrm{~s}) ; v(\mathrm{Sn}-\mathrm{N}), 410(\mathrm{w})$; $v(\mathrm{Sn}-\mathrm{Cl}), 270$ (s). ${ }^{1} \mathrm{H}$ NMR $\left(\mathrm{DMF}-d_{7}\right), \delta(\mathrm{ppm}): 8.51(4 \mathrm{H}, \mathrm{m}$, H6); 8.38-8.25 (8H, m, H3, H4); 7.95 (4H, m, H5); 7.89 (4H, m, H, $\mathrm{Ph}) ; 7.55-7.47\left(6 \mathrm{H}, \mathrm{m}, \mathrm{H}_{\mathrm{m}}, \mathrm{H}_{\mathrm{p}}, \mathrm{Ph}\right) .{ }^{13} \mathrm{C}\left\{{ }^{1} \mathrm{H}\right\}$ NMR (DMF- $\left.d_{7}\right), \delta$ (ppm): 157.1 (C2, pyrazine ring); 154.5 (C2); 152.3 (C6); 143.8 (C3); 140.6 (C4) 130.8 (C5); 142.6 $\left(\mathrm{C}_{\mathrm{ipso}}\right) ; 134.8\left(\mathrm{C}_{\mathrm{o}}\right) ; 131.3\left(\mathrm{C}_{\mathrm{p}}\right) ; 128.1\left(\mathrm{C}_{\mathrm{m}}\right)$.
Data for 4. mp: $256{ }^{\circ} \mathrm{C}$ (dec). Anal. Calc. for $\mathrm{C}_{26} \mathrm{H}_{22} \mathrm{~N}_{6} \mathrm{Cl}_{6} \mathrm{Sn}_{2}: \mathrm{C}, 35.9 ; \mathrm{H}, 2.6 ; \mathrm{N}, 9.7 ; \mathrm{Sn}, 27.3 \%$. Found: $\mathrm{C}, 37.7 ; \mathrm{H}, 2.8 ; \mathrm{N}, 10.2 ; \mathrm{Sn}, 27.0 \%$. IR $v_{\text {max }} / \mathrm{cm}^{-1}: v(\mathrm{CH})$, 3060 (m), 2913 (m); $v(\mathrm{CC} / \mathrm{CN}), 1599(\mathrm{~s}), 1572(\mathrm{~s}), 1486$ (s), $1380(\mathrm{~s}) ; \delta(\mathrm{CH}), 776(\mathrm{~s}), 739(\mathrm{~s}) ; v(\mathrm{Sn}-\mathrm{N}), 408(\mathrm{w}) ;$ $v(\mathrm{Sn}-\mathrm{Cl}), 273$ (s). ${ }^{1} \mathrm{H} \mathrm{NMR}\left(\mathrm{CD}_{3} \mathrm{CN}\right), \delta(\mathrm{ppm}): 8.53(4 \mathrm{H}, \mathrm{m}$, H6); 8.34-8.21 (8H, m, H3, H4); 7.92 (4H, m, H5); 1.27 $(6 \mathrm{H}, \mathrm{Me}) \cdot{ }^{13} \mathrm{C}\left\{{ }^{1} \mathrm{H}\right\}$ NMR $\left(\mathrm{CD}_{3} \mathrm{CN}\right), \delta(\mathrm{ppm}): 156.5(\mathrm{C} 2$, pyrazine ring); 153.3 (C2); 152.4 (C6); 142.7 (C3); 141.3 (C4); 130.6 (C5); 28.7 (Me).

Data for 5. mp: $210{ }^{\circ} \mathrm{C}$ (dec). Anal. Calc. for $\mathrm{C}_{48} \mathrm{H}_{36} \mathrm{~N}_{6} \mathrm{Cl}_{4} \mathrm{Sn}_{2}: \mathrm{C}, 53.6 ; \mathrm{H}, 3.4 ; \mathrm{N}, 7.8 ; \mathrm{Sn}, 22.1 \%$. Found: C, 51.9; H, 3.1; N, 7.6; Sn, 21.6\%. IR $v_{\max } / \mathrm{cm}^{-1}: v(\mathrm{CH})$, $3080(\mathrm{~m}), 3061(\mathrm{~m}) ; v(\mathrm{CC} / \mathrm{CN}), 1596(\mathrm{~s}), 1576(\mathrm{~s}), 1478$ (s), $1400(\mathrm{~s}) ; \delta(\mathrm{CH}), 796(\mathrm{~s}), 732(\mathrm{~s}), 719(\mathrm{~s}) ; \nu(\mathrm{Sn}-\mathrm{N}), 402$ (w); $v$ ( $\mathrm{Sn}-\mathrm{Cl}), 270$ (s). ${ }^{1} \mathrm{H}$ NMR $\left(\mathrm{CD}_{3} \mathrm{CN}\right), \delta$ (ppm): 8.50 (4H, m, H6); 8.43-8.29 (8H, m, H3, H4); 7.93 (4H, m, H5); 7.85 (8H, m, $\left.\mathrm{H}_{\mathrm{o}}, \mathrm{Ph}\right) ; 7.57-7.45\left(12 \mathrm{H}, \mathrm{m}, \mathrm{H}_{\mathrm{m}}, \mathrm{H}_{\mathrm{p}}, \mathrm{Ph}\right) .{ }^{13} \mathrm{C}\left\{{ }^{1} \mathrm{H}\right\}$ NMR $\left(\mathrm{CD}_{3} \mathrm{CN}\right), \delta$ (ppm): 155.1 (C2, pyrazine ring); 153.1 (C2); 152.5 (C6); 144.6 (C3); 140.1 (C4); 129.5 (C5); 141.2 $\left(\mathrm{C}_{\mathrm{ipso}}\right) ; 135.5\left(\mathrm{C}_{\mathrm{o}}\right) ; 132.7\left(\mathrm{C}_{\mathrm{p}}\right) ; 127.6\left(\mathrm{C}_{\mathrm{m}}\right)$.

Synthesis of $\left[\left(\mathrm{SnCl}_{2}\right)_{2}-\mu-\mathrm{TPP}\right](\mathbf{6})$

Solid TPP (0.36 g, $0.93 \mathrm{mmol})$ was added under vigorous magnetic stirring to a solution of anhydrous $\mathrm{SnCl}_{2}$ $(0.41 \mathrm{~g}, 2.17 \mathrm{mmol})$ in EtOH $(25 \mathrm{~mL})$. A yellow solid immediately precipitated. The reaction mixture was kept under stirring for two additional days at room temperature. The yellow solid was then isolated by filtration, washed with $\mathrm{EtOH}$ and $\mathrm{MeOH}$, and dried under vacuum. After drying, product 6 became orange and was stored under argon. The yield of 6 was $0.50 \mathrm{~g}(70 \%)$.

Data for 6. mp: $190{ }^{\circ} \mathrm{C}$ (dec). Anal. Calc. for $\mathrm{C}_{24} \mathrm{H}_{16} \mathrm{~N}_{6} \mathrm{Cl}_{4} \mathrm{Sn}_{2}: \mathrm{C}, 37.6 ; \mathrm{H}, 2.1 ; \mathrm{N}, 11.0 ; \mathrm{Sn}, 30.9 \%$. Found: C, 39.6; H, 1.7; N, 11.2; Sn, 30.7\%. IR $v_{\text {max }} / \mathrm{cm}^{-1}$ : $v(\mathrm{CH}), 3074(\mathrm{w}), 3031(\mathrm{w}) ; v(\mathrm{CC} / \mathrm{CN}), 1592(\mathrm{~s}), 1569(\mathrm{w})$, $1525(\mathrm{w}), 1482(\mathrm{~m}), 1446(\mathrm{~m}), 1397(\mathrm{vs}) ; \delta(\mathrm{CH}), 797(\mathrm{~m})$, 747 (m); $v(\mathrm{Sn}-\mathrm{N}), 456$ (w), $416(\mathrm{~m}) ; \boldsymbol{v}(\mathrm{Sn}-\mathrm{Cl}), 253$ (s), 229 (m). ${ }^{1} \mathrm{H} \mathrm{NMR}\left(\mathrm{CD}_{3} \mathrm{CN}\right), \delta(\mathrm{ppm}): 8.47\left(4 \mathrm{H}, \mathrm{d}, J_{\mathrm{HH}}=4.5 \mathrm{~Hz}\right.$, H6); 8.05-7.96 (8H, m, H3, H4); 7.59 (4H, m, H5). ${ }^{13} \mathrm{C}-$ CP/MAS, $\delta$ (ppm): C2-pyrazine ring: not observable; 150.3 (C2); 147.9 (C6); 143.7 (C3); 140.6 (C4); 128.0 (C5). Due to the low solubility of 6 in commom deuterated solvents and decomposition in DMF- $d_{7}$ and DMSO- $d_{6}$, its solution ${ }^{13} \mathrm{C}\left\{{ }^{1} \mathrm{H}\right\}$ and ${ }^{119} \mathrm{Sn}$ NMR spectra could not be measured.

Because of their importance for the present study, the ${ }^{119} \mathrm{Sn}$ NMR and Mössbauer spectroscopic data are separately listed in Table 1. 
Table 1. ${ }^{119}$ Sn NMR and Mössbauer spectral data

\begin{tabular}{|c|c|c|c|}
\hline \multirow[b]{2}{*}{ Compound } & \multirow{2}{*}{$\begin{array}{c}{ }^{119} \mathrm{Sn} \text { NMR } \\
\delta(\mathrm{ppm})\end{array}$} & \multicolumn{2}{|c|}{${ }^{119} \mathrm{Sn}$ Mössbauer } \\
\hline & & $\delta\left(\mathrm{mm} \mathrm{s}^{-1}\right)$ & $\Delta \mathrm{E}_{\mathrm{Q}}\left(\mathrm{mm} \mathrm{s}^{-1}\right)$ \\
\hline $\mathrm{SnCl}_{4}$ & $\begin{array}{l}-150^{\mathrm{a}, 21} \\
-601^{\mathrm{b}, 22}\end{array}$ & $0.85^{21}$ & 0.00 \\
\hline $\mathrm{SnBr}_{4}$ & $-638^{\mathrm{c}, 21}$ & $1.15^{21}$ & 0.00 \\
\hline $\mathrm{SnCl}_{2}{ }_{2}$ & $-358^{\mathrm{d}, 21}$ & $4.06(2)^{24}$ & $0.66(4)$ \\
\hline $\mathrm{CsSnCl}_{3}$ & $-30^{\mathrm{e}, 21}$ & $3.40^{25}$ & 1.22 \\
\hline $\mathrm{SnPhCl}_{3}$ & $-63^{\mathrm{f}, 23}$ & $1.10^{26}$ & 1.80 \\
\hline $\mathrm{SnMeCl}_{3}^{3}$ & $+20^{\mathrm{g}, 23}$ & $1.20^{27}$ & 1.99 \\
\hline $\mathrm{SnPh}_{2} \mathrm{Cl}_{2}$ & $-32^{\mathrm{f}, 23}$ & $1.40^{26}$ & 2.80 \\
\hline (1) & $-631^{\mathrm{h}}$ & $0.49(1)$ & $0.32(2)$ \\
\hline (2) & $-485^{i}$ & $0.81(1)$ & $0.38(2)$ \\
\hline (3) & $-675^{h}$ & $0.68(1)$ & $2.10(2)$ \\
\hline (4) & $-610^{\mathrm{i}}$ & $0.79(1)$ & $2.08(2)$ \\
\hline (5) & $-640^{i}$ & $1.23(1)$ & $3.45(1)$ \\
\hline (6) & $-584^{j}$ & $3.44(5)$ & $1.14(6)$ \\
\hline
\end{tabular}

${ }^{\mathrm{a}}$ neat; ${ }^{\mathrm{b}}$ in $\mathrm{MeOH} ;{ }^{\mathrm{c}}$ in $\mathrm{CS}_{2} ;{ }^{\mathrm{d}}$ in DMSO; ${ }^{\mathrm{e}}$ in $\mathrm{CH}_{2} \mathrm{Cl}_{2} / \mathrm{C}_{6} \mathrm{D}_{6} ;{ }^{\mathrm{f}}$ in $\mathrm{CD}_{2} \mathrm{Cl}_{2}$; ${ }^{\mathrm{g}}$ in $\mathrm{CDCl}_{3} ;{ }^{\mathrm{h}}$ in DMF- $d_{7} ;{ }^{i}$ in $\mathrm{CD}_{3} \mathrm{CN} ;{ }^{\mathrm{j}}$ solid state.

\section{Results and Discussion}

Elemental analyses agree with the supposition that all products are bimetallic adducts of general formula $\left[\left(\mathrm{SnL}_{n}\right)_{2} \mathrm{TPP}\right]$, in which $\mathrm{SnL}_{n}$ stands for the different stannylated precursors. The analytical and spectroscopic data point to the fact that complexes $\mathbf{1}$ to $\mathbf{5}$ have two hexacoordinate $\mathrm{Sn}(\mathrm{IV})$ sites, whereas complex $\mathbf{6}$ has two tetracoordinate $\mathrm{Sn}(\mathrm{II})$ centers.

In the IR spectra, the $v(\mathrm{CC} / \mathrm{CN})$ bands were shifted from $1590-1390 \mathrm{~cm}^{-1}$ in free TPP to higher wavenumbers in the products. Additionally, new $v(\mathrm{Sn}-\mathrm{N})$ bands appeared in the low-frequency region of the spectra, as expected. Moreover, the $v(\mathrm{Sn}-\mathrm{X})(\mathrm{X}=\mathrm{Cl}$ or $\mathrm{Br})$ bands were shifted to lower wavenumber values in relation to the free stannylated reagents.

The coordination of TPP is also indicated by the ${ }^{1} \mathrm{H}$ and ${ }^{13} \mathrm{C}\left\{{ }^{1} \mathrm{H}\right\}$ (or ${ }^{13} \mathrm{C}-\mathrm{CP} / \mathrm{MAS}$ in the case of 6 ) NMR data. With no exception, the NMR signals assigned to the $\mathrm{H}$ and $\mathrm{C}$ atoms of TPP in the products moved to higher $\delta$ values with respect to those of the free ligand. Moreover, the number and integration of the ${ }^{1} \mathrm{H}$ signals imply that there are no uncoordinated pyridine rings in $\mathbf{1}$ to $\mathbf{6}$, suggesting that TPP may be symmetrically attached to both metallic centers in each adduct. Thus, on the basis of the ${ }^{1} \mathrm{H}$ and ${ }^{13} \mathrm{C}$ NMR spectra, only the bis-bidentate 1 or bis-tridentate chelating modes (Figure 1) can occur in $\mathbf{1}$ to $\mathbf{6}$.

Table 1 shows the ${ }^{119} \mathrm{Sn}$ NMR and ${ }^{119} \mathrm{Sn}$ Mössbauer spectral data collected for the products and for other tin compounds. Our six adducts exhibit only one sharp ${ }^{119} \mathrm{Sn}$ NMR signal. This indicates that both tin atoms in each bimetallic product are chemically and magnetically equivalent in the NMR time scale. Except for 2, the ${ }^{119} \mathrm{Sn}$ chemical shift values, $\delta\left({ }^{119} \mathrm{Sn}\right)$, for the products are significantly lower than those for their precursors. An important feature of ${ }^{119} \mathrm{Sn}$ chemical shifts is that an increase in coordination number normally leads to lower values of $\delta\left({ }^{119} \mathrm{Sn}\right)$ due to shielding effects. ${ }^{19}$ This shift upon complexation has been repeatedly shown in work by this group and by others. ${ }^{23,28-31}$ If one takes $\mathrm{SnCl}_{4}$, its values of $\delta\left({ }^{119} \mathrm{Sn}\right)$ are - 150 and $-601 \mathrm{ppm}$ as the neat compound and in its $\mathrm{MeOH}$ solution, respectively (Table 1). This difference suggests that in $\mathrm{MeOH}$ the metal is hexacoordinate due to solvation. In fact, the value of $\delta\left({ }^{119} \mathrm{Sn}\right)$ observed for $\mathrm{SnCl}_{4}$ in $\mathrm{MeOH}$ is analogous to that measured for $\mathbf{1}$ (Table 1). A more striking case arises when one compares $\mathbf{1}$ with $\left[\mathrm{SnCl}_{4}(\mathrm{DPS})\right]^{31}$ (DPS = di (2-pyridyl)sulfide), in which $\delta\left({ }^{119} \mathrm{Sn}\right)$ is $-636 \mathrm{ppm}$ in DMF- $d_{7}$ and the ligand DPS forms an N,N-bonded chelate. The similarity between the $\delta\left({ }^{119} \mathrm{Sn}\right)$ values for both $\left[\left(\mathrm{SnCl}_{4}\right)_{2}-\mu\right.$-TPP $]$ and $\left[\mathrm{SnCl}_{4}(\mathrm{DPS})\right]$ suggests that in the former each $\mathrm{Sn}(\mathrm{IV})$ center is hexacoordinate and thus, TPP binds to each stannylated site through two pyridine nitrogen atoms, according to the bis-bidentate 1 coordination mode (Figure 1). The same interpretation can be made by comparing $\delta\left({ }^{119} \mathrm{Sn}\right)$ of $2(-485 \mathrm{ppm})$ with that of $\left[\mathrm{SnBr}_{4}(\mathrm{DPS})\right](-502 \mathrm{ppm}) .{ }^{31}$ Curiously, the value of $\delta\left({ }^{119} \mathrm{Sn}\right)$ of $\mathrm{SnBr}_{4}$ (Table 1) is lower than that measured for 2. It has been pointed out that, for adducts obtained from $\mathrm{SnBr}_{4}$, there appears to be no obvious relationship between the coordination number of tin and the value of $\delta\left({ }^{119} \mathrm{Sn}\right){ }^{28}$ In 3 to 5 the upfield shift in the values of $\delta\left({ }^{119} \mathrm{Sn}\right.$ ) (Table 1), in relation to their precursors, also suggests the formation of hexacoordinate $\mathrm{Sn}(\mathrm{IV})$ compounds.

Summing up the discussion in terms of the NMR results, of the seven coordinating possibilities so far reported for TPP (Figure 1), only the symmetrical bis-bidentate 1 and bis-tridentate are possible for $\mathbf{1}$ to $\mathbf{6}$. Both afford equivalent tin centers; nevertheless, the former leads to hexacoordinate $\mathrm{Sn}(\mathrm{IV})$ and tetracoordinate $\mathrm{Sn}$ (II) centers, whereas the latter leads to heptacoordinate $\mathrm{Sn}(\mathrm{IV})$ and pentacoordinate $\mathrm{Sn}(\mathrm{II})$ products. Heptacoordinate Sn(IV) complexes, however, have much lower ${ }^{119} \mathrm{Sn}$ chemical shifts than those obtained for $\mathbf{1}$ to 5. ${ }^{30,32}$ Therefore, the ${ }^{119} \mathrm{Sn}$ NMR results point to hexacoordinate tin centers in the $\mathrm{Sn}(\mathrm{IV})$ products. With respect to complex $\mathbf{6}$, since only a few data about ${ }^{119} \mathrm{Sn}$ MAS NMR spectra of $\mathrm{Sn}(\mathrm{II})$ compounds are available for comparison with our result, a discussion concerning the coordination mode of TPP in 6 will be centered on its ${ }^{119} \mathrm{Sn}$ Mössbauer spectrum. In turn, the ${ }^{119} \mathrm{Sn}$ Mössbauer data of the $\mathrm{Sn}(\mathrm{IV})$ adducts corroborate the conclusions from the ${ }^{119} \mathrm{Sn}$ NMR spectra. This shows that TPP acts as a bisbidentate 1 ligand in both solution and the solid state and leads to the conclusion that no dissociation of complexes $\mathbf{1}$ to $\mathbf{5}$ in coordinating solvents (DMF- $d_{7}$ or $\mathrm{CD}_{3} \mathrm{CN}$ ) occurred. 
Table 1 gives the ${ }^{119} \mathrm{Sn}$ Mössbauer parameters for the precursors and products. Both isomer shifts $(\delta)$ and quadrupole splittings $\left(\Delta \mathrm{E}_{\mathrm{Q}}\right)$ show great variation upon complexation. Invariably, the isomer shift values of $\mathbf{1}$ to $\mathbf{6}$ are lower than those of their precursors. Furthermore, the presence of only one doublet in the ${ }^{119} \mathrm{Sn}$ Mössbauer spectra also indicates the existence of just one type of tin atom in each dinuclear adduct.

${ }^{119} \mathrm{Sn}$ Mössbauer $\delta$ values are directly dependent upon the $5 s$-electron density at the Sn nucleus. ${ }^{17-19,21}$ Thus, an increase in the coordination number of tin leads to a decrease in the $\delta$ value. ${ }^{119} \mathrm{Sn}$ Mössbauer spectroscopy can also be reliably used to distinguish between the $2+$ and $4+$ oxidation states of tin. Usually, $\delta$ values in the interval from -0.5 to $2.1 \mathrm{~mm} \mathrm{~s}^{-1}$ are expected for $\mathrm{Sn}(\mathrm{IV})$ compounds, and $\mathrm{Sn}$ (II) complexes present $\delta$ values ranging from +2.5 to $5.0 \mathrm{~mm} \mathrm{~s}^{-1} .^{21}$ Based on this, our Mössbauer data are consistent with the presence of $\mathrm{Sn}(\mathrm{IV})$ sites in complexes $\mathbf{1}$ to $\mathbf{5}$ and $\mathrm{Sn}(\mathrm{II})$ centers in $\mathbf{6} . \Delta \mathrm{E}_{\mathrm{Q}}$ parameters relate to a change in the symmetry of electron density distribution around the Sn nucleus. ${ }^{17-19,21}$ The three inorganic precursors have $\Delta \mathrm{E}_{\mathrm{Q}}$ values of zero $\left(\mathrm{SnCl}_{4}\right.$ and $\left.\mathrm{SnBr}_{4}\right)$ or very low $\left(\mathrm{SnCl}_{2}\right)$. After complexation, the $\Delta \mathrm{E}_{\mathrm{Q}}$ values of $\mathbf{1 , 2}$, and $\mathbf{6}$ became higher than those of their precursors, showing an increase in electron density asymmetry around the $\mathrm{Sn}$ centers. A similar increase in $\Delta \mathrm{E}_{\mathrm{Q}}$ values also takes place upon coordination of the three organotin reagents.

In all the $\mathrm{Sn}(\mathrm{IV})$ complexes the $5 s$-electron density at tin was reduced from about $25 \%$ ( $s p^{3}$ hybrid) in the precursors to $c a$. $17 \%\left(s p^{3} d^{2}\right.$ hybrid, supposing hexacoordinate tin) in the complexes, entailing a reduction in the $\delta$ values. Regarding the actual isomer shifts, it is interesting to draw attention to the change observed when one compares $\mathrm{SnCl}_{4}\left(0.85 \mathrm{~mm} \mathrm{~s}^{-1}\right)$ with $\left[\mathrm{SnCl}_{4}(\mathrm{DPS})\right](0.48$ $\left.\mathrm{mm} \mathrm{s}^{-1}\right)^{31}$ and $\left[\left(\mathrm{SnCl}_{4}\right)_{2}-\mu\right.$-TPP $\left(0.49 \mathrm{~mm} \mathrm{~s}^{-1}\right)$. Also, a similar change is verified comparing $\mathrm{SnBr}_{4}\left(1.15 \mathrm{~mm} \mathrm{~s}^{-1}\right)$ with $\left[\mathrm{SnBr}_{4}(\mathrm{DPS})\right]\left(0.74 \mathrm{~mm} \mathrm{~s}^{-1}\right)^{31}$ and $\left[\left(\mathrm{SnBr}_{4}\right)_{2}-\mu\right.$-TPP] $(0.81$ $\mathrm{mm} \mathrm{s}^{-1}$ ). These results indicate not only an increase in the coordination number of tin, from four to six, in $\mathbf{1}$ and $\mathbf{2}$, but also similar coordinating environments around tin in the DPS and TPP complexes of $\mathrm{SnCl}_{4}$ and $\mathrm{SnBr}_{4}$. Other analogies arise when one takes the $\delta$ values of $\left[\left(\mathrm{SnPhCl}_{3}\right)_{2}{ }^{-}\right.$ $\mu$-TPP] $\left(0.68 \mathrm{~mm} \mathrm{~s}^{-1}\right)$ and $\left[\mathrm{SnPhCl}_{3}\right.$ (bipy)] (bipy $=2,2^{\prime}$ bipyridine) $\left(0.87 \mathrm{~mm} \mathrm{~s}^{-1}\right),{ }^{33}\left[\left(\mathrm{SnMeCl}_{3}\right)_{2}-\mu\right.$-TPP $](0.79 \mathrm{~mm}$ $\left.\mathrm{s}^{-1}\right)$ and $\left[\mathrm{SnBuCl}_{3}(\right.$ bipy $\left.)\right]\left(0.87 \mathrm{~mm} \mathrm{~s}^{-1}\right),{ }^{33}$ as well as the $\delta$ values of $\left[\left(\mathrm{SnPh}_{2} \mathrm{Cl}_{2}\right)_{2}-\mu\right.$-TPP $]\left(1.23 \mathrm{~mm} \mathrm{~s}^{-1}\right)$, $\left[\mathrm{SnPh}_{2} \mathrm{Cl}_{2}\right.$ (bipy)] $\left(1.22 \mathrm{~mm} \mathrm{~s}^{-1}\right),{ }^{26}$ and $\left[\mathrm{SnPh}_{2} \mathrm{Cl}_{2}(\right.$ bipym $\left.)\right]$ (bipym $=2,2$ '-bipyrimidine) $\left(1.23 \mathrm{~mm} \mathrm{~s}^{-1}\right) \cdot{ }^{2}$ Insofar as [SnPhCl (bipy)], [ $\mathrm{SnBuCl}_{3}$ (bipy)], [ $\mathrm{SnPh}_{2} \mathrm{Cl}_{2}$ (bipy)], and $\left[\mathrm{SnPh}_{2} \mathrm{Cl}_{2}\right.$ (bipym)] have hexacoordinate tin atoms attached to pyridine (or pyrimidine) nitrogen atoms, $\mathbf{3}, \mathbf{4}$, and $\mathbf{5}$ should also be hexacoordinate and in these complexes the tin atoms should be coordinated to the pyridine nitrogen atoms of TPP. In the bipym complex $\left[\mathrm{SnPh}_{2} \mathrm{Cl}_{2}\right.$ (bipym)] the value of $\Delta \mathrm{E}_{\mathrm{Q}}$ is $3.43 \mathrm{~mm} \mathrm{~s}^{-1}$, and its $\mathrm{X}$-ray structure shows that the two $\mathrm{Ph}$ groups are trans to each other. ${ }^{34} \mathrm{In}$ $\left[\left(\mathrm{SnPh}_{2} \mathrm{Cl}_{2}\right)_{2}-\mu\right.$-TPP], 5, $\Delta \mathrm{E}_{\mathrm{Q}}=3.45 \mathrm{~mm} \mathrm{~s}^{-1}$. This proximity in the values of $\Delta \mathrm{E}_{\mathrm{Q}}$ suggests similar geometries for both complexes, thereby pointing that in $\mathbf{5}$ the two $\mathrm{Ph}$ groups must also be trans to each other. Indeed, $\Delta \mathrm{E}_{\mathrm{Q}}$ can be used as a powerful tool for the assignment of structures of cis and trans diorganotin compounds of the $\mathrm{SnR}_{2} \mathrm{Cl}_{2}(\mathrm{LL})$ type, in which LL stands for a bidentate ligand. ${ }^{19}$ It is expected, therefore, that trans complexes show $\Delta \mathrm{E}_{\mathrm{Q}}$ values of about $4.0 \mathrm{~mm} \mathrm{~s}^{-1}$, whereas cis isomers exhibit $\Delta \mathrm{E}_{\mathrm{Q}}$ values twice as smaller. Our conclusion is that $\mathbf{5}$ is likely to have the two $\mathrm{Ph}$ groups trans to each other.

In solid anhydrous tin(II) chloride, the tin atom is surrounded by nine chlorine atoms, leading to a facially capped trigonal prismatic arrangement. ${ }^{21,35}$ Of the nine $\mathrm{Sn}$ $\mathrm{Cl}$ distances in solid $\mathrm{SnCl}_{2}$, three are very short and the others are longer and of variable length. In view of this, it is not possible to clearly state the coordination number of tin in solid $\mathrm{SnCl}_{2}$. Thus, it is difficult to discuss the coordination number of tin in $\mathbf{6}$ solely from a comparison between its Mössbauer parameters and those of $\mathrm{SnCl}_{2}$. On the other hand, in the related compound $\left.\left[\mathrm{SnCl}_{2} \text { (pyridine) }\right)_{2}\right]$ $\delta$ is $3.02 \mathrm{~mm} \mathrm{~s}^{-1}$. 36 The $\delta$ value of $\mathbf{6}, 3.44 \mathrm{~mm} \mathrm{~s}^{-1}$, is very similar to that of $\left.\left[\mathrm{SnCl}_{2} \text { (pyridine) }\right)_{2}\right]$, suggesting similar tin environments in both complexes. Thus, we propose that in 6 TPP also coordinates each stannylated center at two pyridine nitrogen atoms, according to the bis-bidentate 1 chelating mode.

It is important to mention that the bis-bidentate 1 , as well as the mono-bidentate 1 chelating modes of TPP do not lead to planar metallacycles, as Figure 1 might suggest. In fact, due to rotation about the single bonds uniting the pyridine rings and the central pyrazine ring, the adjacent pyridine rings of TPP acquire a non-planar configuration upon coordination through the mono- or bis-bidentate 1 bonding modes. ${ }^{12,13}$

\section{Conclusions}

The present work describes an unprecedented case of the reactivity of TPP towards several inorganic and organometallic stannylated species. Six different adducts were prepared, and all of them are bimetallic species, with TPP bridging two tin centers. From spectroscopic data we conclude that TPP coordinates both Sn(IV) and Sn(II) centers in the same mode, namely the rare bis-bidentate 1 chelating mode. 


\section{Acknowledgements}

The authors are grateful to the Brazilian agencies CAPES, CNPq, FAPERJ, and FUJB for financial support.

\section{References}

1. Thummel, R.P.; Chirayil, S.; Inorg. Chim. Acta 1988, 154, 77.

2. Ruminski, R.; Kiplinger, J.; Cockroft, T.; Chase, C.; Inorg. Chem. 1989, 28, 370.

3. Ruminski, R.R.; Letner, C.; Inorg. Chim. Acta 1989, 162, 175.

4. Ruminski, R.R.; Kiplinger, J.; Inorg. Chem. 1990, $29,4581$.

5. Vogler, L.M.; Scott, B.; Brewer, K.J.; Inorg. Chem. 1993, 32, 898.

6. Graf, M.; Greaves, B.; Stoeckli-Evans, H.; Inorg. Chim. Acta 1993, 204, 239.

7. Brewer, R.G.; Jensen, G.E.; Brewer, K.J.; Inorg. Chem. 1994, 33, 124.

8. Vogler, L.M.; Brewer, K.J.; Inorg. Chem. 1996, 35, 818.

9. Tondreau, V.; Leiva, A.M.; Loeb, B.; Boys, D.; Stultz, L.K.; Meyer, T.J.; Polyhedron 1996, 15, 2035.

10. Graf, M.; Stoekli-Evans, H.; Escuer, A.; Vicente, R.; Inorg. Chim. Acta 1997, 257, 89.

11. Lee, J.-D.; Vrana, L.M.; Bullock, E.R.; Brewer, K.J.; Inorg. Chem. 1998, 37, 3575.

12. Teles, W.M.; Speziali, N.L.; Filgueiras, C.A.L.; Polyhedron 2000, 19, 739 .

13. Chen, X.; Femia, F.J.; Babich, J.W.; Zubieta, J.; Inorg. Chim. Acta 2001, 315, 66.

14. Carranza, J.; Brennan, C.; Sletten, J.; Clemente-Juan, J.M.; Lloret, F.; Julve, M.; Inorg. Chem. 2003, 42, 8716.

15. Lalrempuia, R.; Govindaswamy, P.; Mozharivskyj, Y.A.; Kollipara, M.R.; Polyhedron 2004, 23, 1069.

16. Chanda, N.; Sarkar, B.; Kar, S.; Fiedler, J.; Kaim, W.; Lahiri, G.K.; Inorg. Chem. 2004, 43, 5128.

17. Filgueiras, C.A.L.; Quim. Nova 1998, 21, 176.

18. Gielen, M.; J. Braz. Chem. Soc. 2003, 14, 870.
19. Davies, A.G.; Smith, P.J. In Comprehensive Organometallic Chemistry: The Synthesis, Reactions and Structures of Organometallic Compounds; Wilkinson, G.; Stone, F.G.A.; Abel, E.W., eds.; Pergamon Press: Oxford, 1982, ch. 11.

20. Goodwin, H.A.; Lions, F.; J. Am. Chem. Soc. 1959, 81, 6415.

21. Wardell, J.L. In Encyclopedia of Inorganic Chemistry; King, R.B., ed.; John Wiley \& Sons: Chichester, 1994, p. 41604166.

22. Burke, J.J.; Lauterbur, P.C.; J. Am. Chem. Soc. 1961, 83, 326.

23. Smith, P.J.; Tupiauskas, A.P.; Annu. Rev. NMR Spectrosc. 1978, 8, 291.

24. Birchall, T.; Dean, P.A.W.; Gillespie, R.J.; J. Chem. Soc. A 1971, 1777.

25. Parish, R.V.; Coord. Chem. Rev. 1982, 42, 1.

26. Smith, P.J.; Organomet. Chem. Rev. (A) 1970, 5, 373.

27. Lima, G.M.; Filgueiras, C.A.L.; Abras, A.; Hyperfine Interactions 1994, 83, 183.

28. Wrackmeyer, B.; Annu. Rep. NMR Spectrosc. 1985, 13, 118.

29. Barbieri, R.S.; Beraldo, H.O.; Filgueiras, C.A.L.; Abras, A.; Nixon, J.F.; Hitchcock, P.B.; Inorg. Chim. Acta 1993, 206, 169.

30. Allain, L.R.; Filgueiras, C.A.L.; Abras, A.; Ferreiras, A.G.; J. Braz. Chem. Soc. 1996, 7, 247.

31. Teles, W.M.; Fernandes, N.G.; Abras, A.; Filgueiras, C.A.L.; Trans. Met. Chem. 1999, 24, 321.

32. Blunden, S.J.; Searle, D.; Smith, P.J.; Inorg. Chim. Acta 1986, 116, L31.

33. Mullins, F.P.; Can. J. Chem. 1970, 48, 1677.

34. Caruso, F.; Giomini, M.; Giuliani, A.M.; Rivarola, E.; $J$. Organomet. Chem. 1994, 466, 69.

35. Donaldson, J.D.; Prog. Inorg. Chem. 1968, 8, 287.

36. Ebsworth, E.A.V.; Rankin, D.W.H.; Cradock, S.; Structural Methods in Inorganic Chemistry; Backwell Scientific Publications: Oxford, 1991, ch. 7.

Received: November 5, 2004 Published on the web: July 27, 2005 